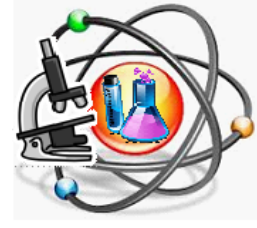

OPEN ACCESS

ISSN 25409859 (online)

Edited by:

Noly Shofiyah

*Correspondence:

Gito Hadiprayitno

gitohadiprayitno@unram.ac.id

Received: 09-10-2020

Accepted: 28-11-2020

Published: $30-11-2020$

Citation:

Hadiprayitno G, Jufri AW and Nufus

SS (2020) Mapping of Students

Scientific Literacy Skills at Mataram.

Science Education Journal (SEJ).

$4: 2$.

doi: $10.21070 /$ sej.v4i2.969

\section{Mapping of Students' Scientific Literacy Skills at Mataram}

\section{Pemetaan Kemampuan Literasi Sains Siswa di Mataram}

\author{
Gito Hadiprayitno ${ }^{1,2 *}$, A Wahab Jufri ${ }^{2}$, Siti Syifa'un Nufus ${ }^{2}$ \\ ${ }^{1}$ Pendidikan Biologi, Universitas Mataram, ${ }^{2}$ Program Studi Magister IPA, Universitas Mataram
}

This study aims to describe the achievement of students' scientific literacy competencies in Integrated Science subjects. Research subjects were class VIII students at MTsN Mataram in the 2019/2020 academic year. The research method was used descriptive with a qualitative approach. Research sampling technique was purposive sampling. Data collection technique used a written test on the aspects of scientific literacy competence according to PISA 2018. Data analysis were used descriptive, Bivariate Correlation test, and Anova test used software application related. The results showed that the students' scientific literacy skills in the Integrated Science including very low category $(40.5 \%)$ with the highest to the lowest achievements in each category a) interpreting data and proving data $(15,4 \%), b)$ test and design scientific investigations (13.6\%), and c) explain phenomena (11.6\%). So, we need more effort to improve and increase students' scientific literacy skills by integrating aspects of scientific literacy competencies during implementing science learning in schools.

Keywords: Science Literacy, Science Learning, PISA

Penelitian ini bertujuan untuk mendeskripsikan capaian kompetensi literasi sains siswa pada mata pelajaran IPA Terpadu. Subjek penelitian ialah siswa kelas VIII di MTsN Mataram tahun ajaran 2019/2020. Metode penelitian secara deskriptif dengan pendekatan kualitatif. Teknik sampling penelitian ialah purposive sampling. Teknik pengambilan data menggunakan tes tulis dengan mengacu pada aspek kompetensi literasi sains menurut PISA 2018. Teknik analisis data secara deskriptif, uji Korelasi Bivariate, dan uji Anova menggunakan aplikasi software terkait. Hasil penelitian menunjukkan bahwa secara umum kemampuan literasi sains siswa pada mata pelajaran IPA Terpadu termasuk kategori sangat rendah $(40,5 \%)$ dengan capaian tertinggi hingga terendah pada tiap aspek secara diantaranya: a) menginterpretasi data dan membuktikan data secara ilmiah $(15,4 \%)$, b) mengevaluasi dan mendesain penyelidikan secara ilmiah (13,6\%), serta c) menjelaskan fenomena secara ilmiah $(11,6 \%)$. Karena itu diperlukan upaya untuk memperbaiki dan meningkatkan kemampuan literasi sains siswa dengan mengintegrasikan aspek kompetensi literasi sains selama pelaksanaan pembelajaran sains di sekolah.

Kata Kunci: Literasi Sains, Pembelajaran Sains, PISA 


\section{PENDAHULUAN}

Setiap negara di dunia saat ini telah memasuki era revolusi industri 4.0, termasuk negara Indonesia. Menurut Lase (2019) karakteristik era tersebut ditandai dengan meningkatnya konektivitas, interaksi, dan perkembangan sistem digital, kecerdasan artifisial, serta virtual. Hal tersebut menjadikan semakin kovergensinya manusia dengan mesin, sumber daya, serta teknologi informasi dan komunikasi yang berdampak terhadap sistem kehidupan, salah satunya sistem pendidikan di Indonesia. Dalam menghadapi tantangan era revolusi industri 4.0, maka Indonesia harus menetapkan orientasi terhadap tujuan utama dari pendidikan sains dengan menciptakan siswa yang melek sains (scientifically literate) atau memiliki kecakapan sains dalam mempersiapkan sumber daya unggul secara soft skill maupun hard skill (Oecd (2019) ; Freshman (2018) ; Yuliati and Saputra (2019) ; Ariningtyas et al. (2017)). Tujuan tersebut dapat diupayakan melalui pembelajaran dengan pendekatan saintifik (Mijaya et al. (2019)).

Organisation for Economic Co-operation and Development (OECD) melalui The Programme for International Student Assessment (PISA) menyelenggarakan survei pada anak usia 15 tahun dalam menilai capaian pengetahuan dan keterampilan setiap tiga tahun sekali. Subjek penilaian PISA berfokus pada literasi membaca, literasi matematika, dan literasi sains (Oecd (2019)). Literasi sains merupakan kemampuan menggunakan pengetahuan untuk mengidentifikasi permasalahan dan menarik kesimpulan berdasarkan bukti-bukti dalam rangka memahami serta membuat keputusan tentang alam dan perbuatan yang dilakukan terhadap alam melalui aktivitas manusia. Indonesia merupakan salah satu dari negara peserta yang berpartisipasi dalam PISA sejak tahun 2000. Semenjak saat itu capaian prestasi pada bidang sains terus berfluktuasi, namun secara keseluruhan tetap datar.

Hasil penilaian PISA pada aspek literasi sains siswa Indonesia tahun 2000, 2003, 2006, 2009, dan 2012 secara berturut-turut bernilai 393 poin, 395 poin, 393 poin, 383 poin, dan 382 poin (Ayu and Sunarti (2018) ; Fatkhurrohman and Astuti (2017); Wulandari and Wulandari (2016)). Namun, skor perolehan Indonesia masih jauh di bawah rerata skor OECD yaitu 500 poin. Sedangkan keikutsertaan Indonesia tahun 2015 skor tertinggi dicapai pada aspek literasi sains diantara dua aspek lainnya yaitu sebesar 403 poin (Oecd (2016)). Meskipun mengalami kenaikan, namun rerata skor Indonesia masih berada di bawah rerata skor OECD (Tohir (2016)). Hasil survei terbaru pelaksanaan penilaian PISA 2018 diketahui rerata skor tiga aspek yang diujikan seluruhnya mengalami penurunan, tanpa terkecuali aspek literasi sains dengan rerata skor sebesar 396 poin (Oecd (2019)). Hasil penilaian tersebut sejalan dengan hasil penelitian beberapa sekolah di Indonesia yang menunjukkan bahwa secara umum siswa Indonesia memiliki kemampuan yang rendah dalam aspek literasi sains (Sujudi et al. (2020); Rahmadani et al. (2018); Arohman et al. (2016); Kulsum et al. (2017)). Kondisi tersebut disebabkan karena kurangnya kesiapan siswa dalam mengikuti tes penilaian literasi sains, hasil belajar hanya ditekankan pada aspek kognitif saja, dan kurangnya peran guru dalam mendorong siswa memiliki kemampuan literasi sains (Sujudi et al. (2020)).

Berdasarkan pemaparan uraian di atas, sebaiknya hasil penilaian seperti ini dapat dijadikan sebagai bukti empiris yang kuat bagi sejumlah pendidik sains, pengajar pembelajaran, dan pembuat kebijakan pendidikan dalam memperbaiki dan meningkatkan kualitas pendidikan sains di Indonesia (Setiawan (2019)). Pada kurikulum 2006 (KTSP), literasi sains sudah diterapkan dalam proses pembelajaran. Namun, pelaksanaannya baru terlihat jelas saat kurikulum 2013 dengan mengedepankan pendekatan saintifik dan kegiatan inkuiri (Pertiwi and Firdausi (2019)). Karena itu penting bagi siswa memiliki kemampuan literasi sains sebagai bekal dalam menghadapi berbagai tantangan di era abad 21 (Arohman et al. (2016)).

Oleh karena literasi sains merupakan salah satu indikator pencapaian pembelajaran sains dan dianggap sangat penting untuk dimiliki siswa, maka perlu dilakukan pemetaan. Pemetaan tersebut bertujuan untuk memberikan gambaran terhadap profil kemampuan literasi sains siswa pada mata pelajaran ilmu pengetahuan alam (IPA). Dengan demikian, dapat diketahui letak kurangnya pencapaian siswa pada aspek kompetensi literasi sains yang meliputi: a) menjelaskan fenomena secara ilmiah, b) mengevaluasi dan mendesain penyelidikan secara ilmiah, serta 3) menginterpretasikan data dan membuktikan data secara ilmiah.

\section{METODE PENELITIAN}

Penelitian ini termasuk jenis penelitian deskriptif dengan pendekatan kualitatif. Tujuan penelitian untuk mendeskripsikan capaian kemampuan literasi sains siswa pada mata pelajaran IPA Terpadu. Subjek dalam penelitian ini ialah siswa kelas VIII di MTsN Mataram tahun ajaran 2019/2020. Teknik pengambilan sampel dalam penelitian ini menggunakan purposive sampling yang didasarkan atas tujuan peneliti dengan total sampel sebanyak 100 orang siswa.

Teknik pengumpulan data menggunakan tes tulis berbentuk pilihan ganda (multiple choices) dengan jumlah sebanyak 40 soal yang mengacu pada indikator kompetensi literasi sains menurut PISA 2018 (Oecd (2019)). Kompetensi literasi sains meliputi: 1) menjelaskan fenomena secara ilmiah, 2) mengevaluasi dan mendesain penyelidikan secara ilmiah, serta 3) menginterpretasikan data dan membuktikan data secara ilmiah. Namun, terlebih dahulu dilakukan uji validitas soal menggunakan Pearson Correlation dan uji reliabilitas soal menggunakan Cronbach's Alpha.

Teknik analisis data terhadap capaian kemampuan literasi sains menggunakan teknik deskriptif dengan persentase (\%) melalui penjumlahan jawaban benar siswa dibagi total seluruh soal dikalikan seratus persen. Hasil analisis selanjutnya dikualifikasikan dalam predikat menurut aturan Purwanto (Yuriza et al. (2018)) pada Tabel 1 .

[Table 1 about here.]

Teknik analisis data untuk mengetahui ada tidaknya perbedaan pada tiap aspek kompetensi literasi sains dianalisis menggunakan uji Anova, namun terlebih dahulu dilakukan uji prasyarat meliputi uji normalitas Kolmogorov Smirnov test dan uji homogenitas. Kriteria data tiap aspek kompetensi literasi sains siswa dikatakan terdistribusi normal apabila nilai Signifikansi atau probabilitas $>0,05$. Selanjutnya dilakukan uji Homogenitas menggunakan uji Levene untuk mengetahui data 
tiap aspek kompetensi literasi sains memiliki kesamaan varians atau tidak. Kriteria data dikatakan homogen apabila nilai Signifikansi atau probabilitas $>0,05$. Selanjutnya dilakukan uji Anova untuk mengetahui perbedaaan kemampuan literasi sains siswa pada masing-masing aspek. Apabila uji Anova menunjukkan nilai Signifikansi atau probabilitas $>0,05$ maka data tersebut tidak menunjukkan perbedaan. Namun apabila nilai Signifikansi $<0,05)$ maka dilanjutkan dengan uji post hoct.

\section{HASIL DAN PEMBAHASAN}

Hasil analisis terhadap distribusi frekuensi tiap kategori kemampuan literasi sains siswa pada mata pelajaran IPA Terpadu dapat dilihat pada Gambar 1.

\section{[Figure 1 about here.]}

Berdasarkan Gambar 1 diketahui bahwa mayoritas siswa memiliki kemampuan literasi sains pada kategori sangat rendah (84\%). Sementara itu pada kategori rendah sebanyak 3\% siswa dan kategori sedang sebanyak 13\% siswa.

Penilaian terhadap aspek kompetensi literasi sains menurut PISA 2018 meliputi tiga kompetensi diantaranya: 1) menjelaskan fenomena secara ilmiah, 2) mengevaluasi dan mendesain penyelidikan secara ilmiah, serta 3) menginterpretasikan data dan membuktikan data secara ilmiah. Penilaian ini bertujuan untuk mengukur sejauh mana capaian kemampuan literasi sains setiap siswa Indonesia (Oecd (2016)). Untuk mengetahui hal tersebut, maka terlebih dahulu dilakukan analisis varians dengan tujuan untuk mengetahui ada tidaknya perbedaan pada tiap aspek kompetensi literasi sains. Adapun hasil analisis varians dapat dilihat pada Tabel 2.

\section{[Table 2 about here.]}

Berdasarkan hasil analisis varians diketahui bahwa nilai probability dibawah 0,05. Artinya, terdapat perbedaan kemampuan literasi sains siswa pada masing-masing aspek. Sedangkan untuk nilai perbedaan masing-masing aspek tersebut dilakukan analisis menggunakan uji post hoct yang menunjukkan hasil pada Tabel 3.

\section{[Table 3 about here.]}

Berdasarkan hasil analisis post hoct diketahui bahwa capaian tertinggi pada aspek $3(15,4 \%)$ yaitu menginterpretasi data dan membuktikan data secara ilmiah. Selanjutnya posisi kedua tertinggi pada aspek $2(13,6 \%)$ yaitu mengevaluasi dan mendesain penyelidikan ilmiah, serta capaian terendah pada aspek $1(11,6 \%)$ yaitu menjelaskan fenomena secara ilmiah. Dengan demikian, secara keseluruhan rata-rata capaian kompetensi literasi sains siswa termasuk kategori sangat rendah (40,5\%). Rendahnya capaian tersebut selaras dengan hasil literasi sains siswa Indonesia pada penilaian PISA 2018 (Oecd (2019)). Nilai capaian tiap aspek dapat dilihat pada Gambar 2.

[Figure 2 about here.]

Aspek kompetensi menjelaskan fenomena secara ilmiah memiliki capaian paling rendah diantara dua aspek lainnya.
Hal ini karena kemampuan sebagian besar siswa menggunakan representasi atau model masih sangat rendah. Rendahnya kemampuan tersebut menurut (Lasiani and Rusilowati (2017)) sejalan dengan rendahnya kemampuan literasi sains siswa. Seharusnya dengan adanya representasi dapat memberikan kemudahan bagi siswa untuk memahami informasi atau konsep pengetahuan (Widianingtiyas et al. (2015)). Sehingga siswa tidak lagi mengandalkan ingatannya dalam menyelesaikan permasalahan sains. Diketahui juga bahwa masih terdapat banyak siswa dengan kemampuan sangat rendah dalam memberikan alasan yang tepat terhadap suatu prediksi dan penjelasan mengenai implikasi pengetahuan sains terhadap lingkungan sekitar. Hal ini diduga karena kecenderungan guru saat mengajar tidak mengaitkan konsep pengetahuan dengan kehidupan nyata siswa sehingga menimbulkan kesenjangan ketika siswa dihadapkan pada sejumlah permasalahan sains yang membutuhkan kemampuan lebih dalam menghubungkan berbagai fakta fungsional mengenai sains.

Pada aspek kompetensi mengevaluasi dan mendesain penyelidikan secara ilmiah masih terdapat banyak siswa memiliki kemampuan sangat rendah dalam mengidetifikasi dan membedakan pertanyaan ilmiah, serta mengevaluasi reliabilitas suatu data dan generalisasi suatu penjelasan. Hal tersebut disebabkan karena metode pembelajaran yang diterapkan hanya sebatas metode ceramah tanpa diimbangi oleh kegiatan eksperimen. Hasil penelitian oleh (Sari et al. (2017)) menjelaskan bahwa dengan membiasakan siswa merancang suatu penyelidikan, secara tidak langsung siswa tersebut telah melatih kemampuannya dalam mengidentifikasi pertanyaan untuk selanjutnya dieksplorasi melalui serangkaian penyelidikan ilmiah. Pada aspek kompetensi menginterpretasi dan membuktikan data secara ilmiah sebagian besar siswa memiliki kemampuan dalam menganalisis, menginterpretasi, dan membuat kesimpulan yang tepat, serta kemampuan membedakan argumen yang didasarkan atas bukti dan teori ilmiah dengan yang didasarkan atas pertimbangan lain. Namun, sedikit siswa memiliki kemampuan dalam mengidentifikasi suatu asumsi, bukti, dan penalaran dalam sebuah teks yang berkaitan dengan sains.

Rendahnya kemampuan literasi sains siswa menurut (Hasasiyah et al. (2019)) disebabkan karena implementasi materi ajar selama proses pembelajaran masih bersifat abstrak dan hanya menekankan pada kemampuan menghafal siswa dan belum terbiasa menyelesaikan permasalahan dengan karakteristik soal yang disesuaikan dengan indikator PISA (Huryah et al. (2017)) dan siswa lebih sering dihadapkan pada soal dengan kategori rendah (Rahayuni (2016)). Pernyataan tersebut tercermin dari hasil capaian siswa yang rendah pada aspek kompetensi literasi sains yaitu mengevaluasi dan mendesain penyelidikan secara ilmiah diantara dua aspek lainnya. Selain memuat permasalahan mengenai fenomena ilmiah, soal yang dirancang berdasarkan indikator PISA seharusnya dapat melatih siswa untuk mengeksplor pertanyaan secara ilmiah, membuktikan reliabilitas suatu data, objektifitas suatu data, dan generalisasi suatu penjelasan, serta dapat membedakan pertanyaan yang dapat diinvestigasi secara ilmiah maupun tidak (Oecd (2016)).

Rendahnya kemampuan literasi sains siswa dapat pula disebabkan karena implementasi metode pembelajaran yang hanya mengandalkan presentasi dan kegiatan diskusi kelas 
sebagai bentuk upaya penguatan konsep siswa (Jannah et al. (2019)). Oleh sebab itu perlu dilakukan integrasi prinsip kontruktivisme dalam proses pembelajaran sains sehingga siswa secara mandiri membangun konsep pengetahuannya melalui pengawasan guru sebagai fasilitator (Atiyah et al. (2016)). Penyebab lainnya seperti guru kurang mampu mengaitkan pengetahuan siswa dengan fenomena-fenomena ilmiah yang terjadi di lingkungan sekitar sehingga pembelajaran menjadi kurang bermakna dan relevan bagi siswa (Putri et al. (2020)). Hal tersebut selaras dengan hasil penelitian (Ariningtyas et al. (2017)) yang menyatakan bahwa jangkauan literasi sains yang terjadi di lapangan sebatas memenuhi aspek kemampuan menjelaskan fenomena secara ilmiah belum mengarah kepada aspek kompetensi literasi sains lainnya. Artinya siswa hanya dibekali satu diantara tiga aspek kompetensi literasi sains.

Kemampuan literasi sains penting dimiliki oleh setiap siswa yang mempelajari sains. Pentingnya literasi sains sebagai bekal untuk mempersiapkan siswa memiliki kemampuan dalam mengatasi berbagai permasalahan di masyarakat yang sangat bergantung terhadap keberadaan teknologi dan perkembangan ilmu pengetahuan (Bybee and Mccrae (2011)). Hal tersebut penting agar siswa terhindar dari adanya miskonsepsi terhadap aplikasi sains (Wahyuningsih et al. (2018)).

Pembelajaran sains menitikberatkan pada keterampilan proses sains sebagai bentuk tuntutan terhadap pengalaman belajar lebih tinggi (Susanti et al. (2017)). Keterampilan proses sains mengharuskan siswa untuk terlibat langsung selama proses pembelajaran, sehingga siswa dapat mengekspresikan pemikirannya tentang sains dan mendorong siswa untuk terlibat aktif mengajukan pertanyaan (Atiyah et al. (2016)). Hal tersebut dikarenakan keterampilan proses sains merupakan bagian utama yang memiliki pengaruh terhadap kemampuan literasi sains siswa (Winata et al. (2016)). Selain itu, seiring berkembangnya kemampuan literasi sains, secara tidak langsung siswa telah melatih kemampuan berpikir tingkat tinggi (Asyhari and Hartati (2015); Asyhari (2017)) sesuai dengan cara berpikir IPA (Lepiyanto (2017)). Keberadaan kerja ilmiah berbasis praktikum sangat potensial bagi siswa dalam memahami sains dan mendorong keterampilan proses sains, dengan demikian guru dapat membangun kemampuan literasi sains siswa (Nugraha et al. (2017)).

Upaya memperbaiki dan meningkatkan kemampuan literasi sains siswa dapat dilakukan dengan mengintegrasikan kearifan lokal dan model pembelajaran yang memuat sejumlah fenomena ilmiah dalam pembelajaran sains (Hartini et al. (2018); Basuki et al. (2019)). Hal tersebut selaras dengan pendapat (Jufrida et al. (2019)) yang menyatakan bahwa bahan ajar merupakan perantara kearifan lokal dengan pembela- jaran IPA di sekolah sehingga menjadi salah satu upaya dalam meningkatkan kemampuan literasi sains siswa. Bahan ajar dikatakan baik apabila kandungan materi yang termuat didalamnya dapat memfasilitasi siswa untuk berinteraksi dengan sains, teknologi, dan masyarakat (Pertiwi and Firdausi (2019)). Salah satu contoh bahan ajar yaitu lembar kerja siswa (lks) dengan pendekatan saintifik yang diimplementasikan selama proses pembelajaran juga dapat menjadi solusi dalam meningkatkan kemampuan literasi sains siswa (Arifin and Kuntjoro (2019)). Kemampuan literasi sains siswa rendah pada aspek konten atau menggunakan pengetahuan dapat diatasi dengan memberikan bahan bacaan atau materi mendalam dan bersifat ilmiah, diantaranya seperti artikel, berita, buku, maupun jurnal-jurnal ilmiah (Asyhari and Clara (2017)). Dengan membiasakan siswa menggunakan sumber belajar yang beragam, secara tidak langsung melatih kemampuan menginterpretasi data dan membuktikan data secara ilmiah. Sehingga siswa dapat membuat keputusan atas peristiwa ilmiah yang terjadi. Upaya lain melalui implementasi model discovery learning dengan mengarahkan siswa untuk menemukan sendiri pengetahuan tentang sains yang berdampak terhadap penguatan ingatan, pengertian, dan juga transfer ilmu (Niswatuzzahro et al. (2018)).

\section{KESIMPULAN}

Berdasarkan hasil penelitian dapat disimpulkan bahwa mayoritas siswa pada mata pelajaran IPA Terpadu kelas VIII di MTsN Mataram memiliki kemampuan literasi sains sangat rendah (84\%). Hasil lain menunjukkan bahwa terdapat perbedaan capaian siswa pada tiap aspek kompetensi literasi sains diantaranya didominasi oleh aspek 3 (menginterpretasi data dan membuktikan data secara ilmiah) sebesar 15,4\%, kemudian sebagian besar siswa mencapai kemampuan pada aspek 2 (mengevaluasi dan mendesain penyelidikan secara ilmiah) sebesar 13,6\%, serta beberapa siswa dapat mencapai kemampuan pada aspek 1 (menjelaskan fenomena secara ilmiah) sebesar $11,6 \%$.

\section{UCAPAN TERIMA KASIH}

Ucapan terimakasih atas segala kelancaran dan kemudahan dalam menyelesaikan penelitian ini disampaikan kepada Ayudya Lestari, Nurul Hidayah dan Hidayani atas bantuan serta kerjasamanya. Semoga dengan adanya hasil penelitian ini dapat memberikan motivasi bagi pendidik dalam meningkatkan kualitas pendidikan sains di Indonesia.

\section{REFERENCES}

Arifin and Kuntjoro (2019). Validitas Lembar Kegiatan Siswa (LKPD) Materi Keanekaragaman Hayati Berbasis Saintifik Untuk Melatihkan Keterampilan Literasi Sains Siswa Kelas X. BioEdu 8

Ariningtyas, A., Wardani, S., and Mahatmanti, W. (2017). Efektivitas lembar kerja siswa bermuatan etnosains materi hidrolisis garam untuk meningkatkan literas sains siswa sma. Journal of Innovative Science Education 6, 186-196.

Arohman et al. (2016). Kemampuan literasi sains siswa pada pembelajaran ekosistem. Proceeding Biology Education Conference: Biology, Science, Enviromental, and Learning 13, 90-92.
Asyhari and Clara (2017). Pengaruh Pembelajaran Levels of Inquiry Terhadap Kemampuan Literasi Sains Siswa. Scientiae Educatia 6, 87-87. doi: 10.24235/ sc.educatia.v6i2.2000.

Asyhari, A. (2017). Literasi Sains Berbasis Nilai-Nilai Islam dan Budaya Indonesia Jurnal Ilmiah Pendidikan Fisika Al-Biruni 6, 137-137. doi: 10.24042/jpifalbiruni. v6il.1584.

Asyhari, A. and Hartati, R. (2015). Implementasi Pembelajaran Fisika SMA Berbasis Inkuiri Terbimbing Terintegrasi Pendidikan Karakter untuk Meningkatkan Hasil Belajar Siswa pada Materi Cahaya dan Optika. Jurnal Ilmiah Pendidikan Fisika Al-Biruni 4, 37-49.

Atiyah et al. (2016). Penggunaan lembar kerja siswa (LKS) berbasis Keterampilan 
Proses Sains (KPS) untuk meningkatkan literasi sains siswa pada konsep kingdom plantae Kelas X Di Sman 3 Kuningan. Scientiae Educatia: Jurnal Pendidikan Sains 5, 144-155.

Ayu and Sunarti (2018). Upaya meningkatkan kemampuan literasi sains dengan model pembelajaran guided inquiry pada SMA untuk materi alat optik. Inovas Pendidikan Fisika 7

Basuki, F. R., Kurniawan, W., Jufrida, J., and Kurniawan, D. A. (2019). Pemetaan Kompetensi Dasar dan Integrasi Kearifan Lokal Dalam Pembelajaran IPA SMP di Kabupaten Muaro Jambi. Dedikasi: Jurnal Pengabdian Masyarakat 1, 301-322.

Bybee and Mccrae (2011). Scientific literacy and student attitudes: Perspectives from PISA. science. International Journal of Science Education 33, 7-26.

Fatkhurrohman, M. A. and Astuti, R. K. (2017). Pengembangan Modul Fisika Dasar I Berbasis Literasi Sains. PSEJ (Pancasakti Science Education Journal) 2, 163-163. doi: $10.24905 /$ psej.v2i2.798.

Freshman, P. J. (2018). Science Education Policy Making: Eleven Emerging Issues, and others (ed.) (Paris: UNESCO, Section for Science, Technical and Vocational Education).

Hartini et al. (2018). Pemetaan HOTS Siswa Berdasarkan Standar PISA dan TIMSS untuk Meningkatkan Mutu Pendidikan. Eduma: Mathematics Education Learning and Teaching 7, 83-92.

Hasasiyah et al. (2019). Analisis Kemampuan Literasi Sains Siswa SMP pada Mater Sirkulasi Darah. Jurnal Penelitian Pendidikan IPA 6, 5-5. doi: 10.29303/jppipa. v6i1.193.

Huryah et al. (2017). ANALISIS CAPAIAN LITERASI SAINS BIOLOGI SISWA SMA KELAS X SEKOTA PADANG. JURNAL EKSAKTA PENDIDIKAN (JEP) 1, 72-72. doi: 10.24036/jep.v1i2.70.

Jannah et al. (2019). Analisis Penerapan Pembelajaran Kimia Organik Berkonteks Isu Sosiosainstifik untuk Meningkatkan Literasi Sains Mahasiswa IPA. THABIEA : JOURNAL OF NATURAL SCIENCE TEACHING 2, 45-45. doi: 10.21043/ thabiea.v2i1.5491.

Jufrida et al. (2019). Need Analysis of Science Textbook Based Jambi Local Wisdom to Improve Science Literacy of SMPN 7 Muaro Jambi. Formatif: Jurnal Ilmiah Pendidikan MIPA 9. doi: 10.30998/formatif.v9i2.3340.

Kulsum, F., Rochman, C., and Nasrudin, D. (2017). Profil Literasi Sains Peserta Didik Pada Konsep Pembangkit Listrik Tenaga Air (Plta) Cirata Di Kabupaten Cianjur Jawa Barat. WaPFi (Wahana Pendidikan Fisika 2

Lase (2019). Pendidikan di Era Revolusi Industri 4.0. SUNDERMANN: Jurnal Ilmiah Teologi, Pendidikan, Sains, Humaniora dan Kebudayaan 1, 28-43. doi: 10.36588/sundermann.v1i1.18.

Lasiani and Rusilowati (2017). Pola pemecahan masalah berdasarkan representas siswa dalam membangun pemahaman konsep fisika. Physics Communication 1 $1-7$

Lepiyanto (2017). ANALISIS KETERAMPILAN PROSES SAINS PADA PEMBELAJARAN BERBASIS PRAKTIKUM. BIOEDUKASI (Jurnal Pendidikan Biologi) 5, 156-156. doi: 10.24127/bioedukasi.v5i2.795

Mijaya, N. P. A. P., Sudiatmika, A. A. I. A. R., and Selamet, K. (2019). PROFIL LITERASI SAINS SISWA SMP MELALUI MODEL PEMBELAJARAN LEVELS OF INQUIRY. Jurnal Pendidikan dan Pembelajaran Sains Indonesia (JPPSI) 2 161-161. doi: 10.23887/jppsi.v2i2.19385.

Niswatuzzahro et al. (2018). Penerapan Model Discovery Learning Berbantuan Media Audio Visual untuk Meningkatkan Literasi Sains Siswa Kelas 5 SD. Schol aria: Jurnal Pendidikan dan Kebudayaan 8, 273-284. doi: 10.24246/j.js.2018.v8. i3.p273-284.

Nugraha et al. (2017). Analisis kemampuan berpikir kritis ditinjau dari keterampilan proses sains dan motivasi belajar melalui model pbl. Journal of Primary Education $6,35-43$

Oecd (2016). Country Note - Results from PISA 201 (PISA: OECD Publishing).

Oecd (2019). Indonesia-Country Note PISA 2018 Results Volumes I-III (PISA: OECD Publishing).
Pertiwi and Firdausi (2019). UPAYA MENINGKATKAN LITERASI SAINS MELALUI PEMBELAJARAN BERBASIS ETNOSAINS. Indonesian Journal of Natural Science Education (IJNSE) 2, 120-124. doi: 10.31002/nse.v2i1.476.

Putri et al. (2020). Konversi Agama di Kalangan Etnis Tionghoa: Motivasi, Adaptasi dan Konsekuensi. Hayula: Indonesian Journal of Multidisciplinary Islamic Studies 4, 19-40. doi: 10.21009/004.01.02.

Rahayuni (2016). HUBUNGAN KETERAMPILAN BERPIKIR KRITIS DAN LITERASI SAINS PADA PEMBELAJARAN IPA TERPADU DENGAN MODEL PBM DAN STM. Jurnal Penelitian dan Pembelajaran IPA 2, 131-131. doi: 10.30870/jppi.v2i2.926.

Rahmadani, Y., Fitakurahmah, N., Fungky, N., Prihatin, R., Majid, Q., and Prayitno, B. A. (2018). Profil Keterampilan Literasi Sains Siswa di Salah Satu Sekolah Swasta di Karanganyar. Jurnal Pendidikan Biologi 7, 183-183. doi: 10.24114/jpb. v7i3.10123.

Sari et al. (2017). Pengaruh Pembelajaran Berbasis Proyek terhadap Kemampuan Literasi Sains Siswa. PSEJ (Pancasakti Science Education Journal) 2, 114-114. doi: $10.24905 /$ psej.v2i2.741.

Setiawan (2019). Literasi Saintifik Berdasarkan Kecerdasan Majemuk dan Motivasi Belajar. Media Penelitian Pendidikan: Jurnal Penelitian dalam Bidang Pendidikan dan Pengajaran 13, 126-137.

Sujudi et al. (2020). Profil Kemampuan Literasi Sains Siswa SMP Islam As-Shofa Kota Pekanbaru Berdasarkan PISA. Journal of Natural Science and Integration 3 , 58-58. doi: 10.24014/jnsi.v3i1.9023.

Susanti et al. (2017). PENGEMBANGAN PERANGKAT PEMBELAJARAN IPA MODEL INKUIRI TERBIMBING UNTUK MELATIHKAN KETERAMPILAN PROSES SAINS SISWA SMP. JPPS (Jurnal Penelitian Pendidikan Sains) 6, 1255 1255. doi: 10.26740/jpps.v6n1.p1255-1264.

Tohir, M. (2016). Hasil PISA Indonesia tahun 2015 mengalami peningkatan, 1-2.

Wahyuningsih et al. (2018). Analisis Miskonsepsi Literasi Sains Menggunakan Three Tier Multiple Choice Test Materi Cahaya. Phenomenon: Jurnal Pendidikan MIPA 8, 114-128.

Widianingtiyas, , et al. (2015). Pengaruh Pendekatan Multi Representasi dalam Pembelajaran Fisika Terhadap Kemampuan Kognitif Siswa SMA. Jurnal Penelitian \& Pengembangan Pendidikan Fisika 01, 31-38. doi: 10.21009/1.01105.

Winata et al. (2016). ANALISIS KEMAMPUAN AWAL LITERASI SAINS MAHASISWA PADA KONSEP IPA. Education and Human Development Journal 1, 1-1. doi: 10.33086/ehdj.vli1.291.

Wulandari, N. and Wulandari, N. (2016). ANALISIS KEMAMPUAN LITERAS SAINS PADA ASPEK PENGETAHUAN DAN KOMPETENSI SAINS SISWA SMP PADA MATERI KALOR. EDUSAINS 8, 66-73. doi: 10.15408/es.v8i1.1762.

Yuliati, Y. and Saputra, D. S. (2019). PEMBELAJARAN SAINS DI ERA REVOLUSI INDUSTRI 4.0. Jurnal Cakrawala Pendas 5. doi: 10.31949/jcp.v5i2.1389.

Yuriza et al. (2018). Correlation between higher-order thinking skills and level of intelligence with scientific literacy on junior high school students. Biosfer 11, 13-21. doi: 10.21009/biosferjpb.11-1.2.

Conflict of Interest Statement: The authors declare that the research was conducted in the absence of any commercial or financial relationships that could be construed as a potential conflict of interest.

Copyright () 2020 Hadiprayitno, Jufri and Nufus. This is an open-access article distributed under the terms of the Creative Commons Attribution License (CC BY). The use, distribution or reproduction in other forums is permitted, provided the original author(s) and the copyright owner(s) are credited and that the original publication in this journal is cited, in accordance with accepted academic practice. No use, distribution or reproduction is permitted which does not comply with these terms. 


\section{LIST OF TABLES}

1 Kualifikasi Hasil Persentase Kemampuan Literasi Sains Siswa . . . . . . . . . . . . . . . . . . . . . . . . . . . . 105

2 Uji Anova Tiap Aspek Kompetensi Literasi Sains ～. . . . . . . . . . . . . . . . . . . . . . . . . . . 106

3 Uji Post Hoct Tiap Aspek Kompetensi Literasi Sains ～. . . . . . . . . . . . . . . . . . . . . . . . . . . . 107 
TABLE 1 | Kualifikasi Hasil Persentase Kemampuan Literasi Sains Siswa

\begin{tabular}{ll} 
Persentase & Kategori \\
$86 \%-100 \%$ & Sangat Tinggi \\
$76 \%-86 \%$ & Tinggi \\
$60 \%-75 \%$ & Sedang \\
$55 \%-59 \%$ & Rendah \\
$\leq 54 \%$ & Sangat Rendah \\
\hline
\end{tabular}


TABLE 2 | Uji Anova Tiap Aspek Kompetensi Literasi Sains

\begin{tabular}{llllll}
\hline & Sum of Squares & df & Mean Square & F & Sig \\
\hline Between Groups & 722.667 & 2 & 361.333 & 11.189 & .000 \\
Within Groups & 9592.063 & 297 & 32.293 & & \\
Total & 10313.729 & 299 & & & \\
\hline
\end{tabular}


TABLE 3 | Uji Post Hoct Tiap Aspek Kompetensi Literasi Sains

\begin{tabular}{llcr}
\hline \multicolumn{1}{c}{ Indikator } & N & Subset for alpha = 0.05 \\
\hline Menjelaskan fenomena ilmiah & 100 & 11.5750 & 13.5750 \\
Mengidentifikasi isu & 100 & 100 & 15.3750 \\
Menggunakan bukti ilmiah & 100 & \\
\hline
\end{tabular}




\section{LIST OF FIGURES}

1 Frekuensi Kategori Kemampuan Literasi Sains Siswa . . . . . . . . . . . . . . . . . . . . . . . . . . . . . . . . . . . . . . .

2 Rata-Rata Capaian Tiap Aspek Kompetensi Literasi Sains . . . . . . . . . . . . . . . . . . . . . . . 110 


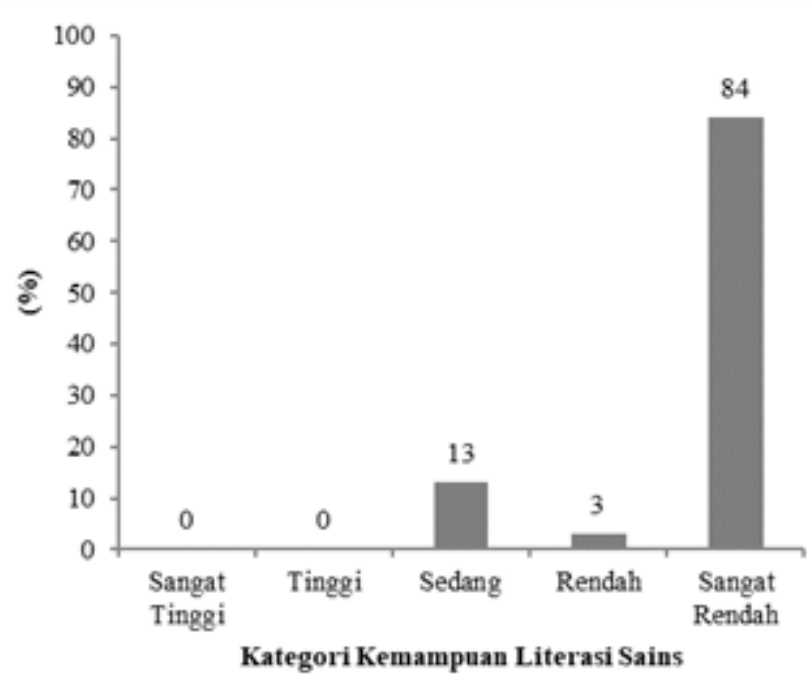

FIGURE 1 | Frekuensi Kategori Kemampuan Literasi Sains Siswa 


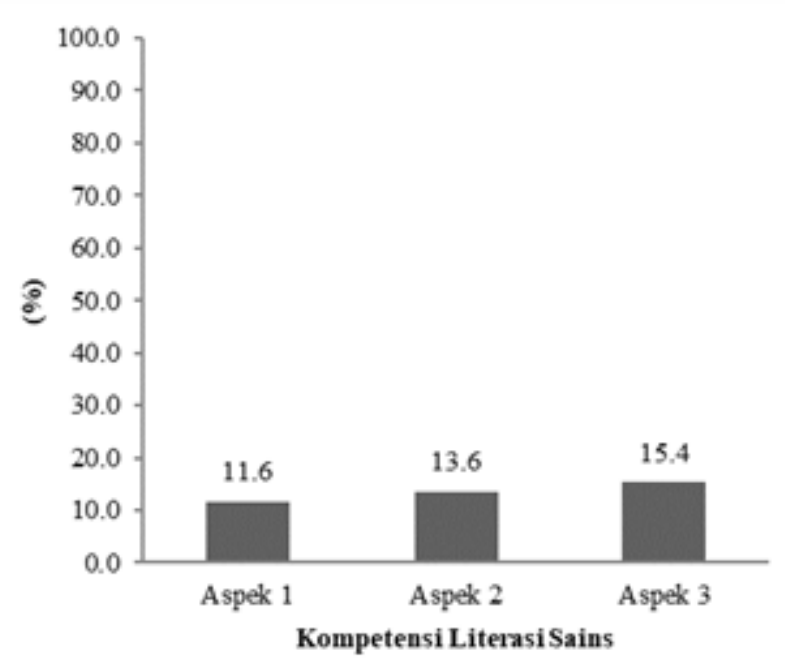

FIGURE 2 | Rata-Rata Capaian Tiap Aspek Kompetensi Literasi Sains 